\title{
ADDENDUM
}

\section{In Your Element: Manganese the protector}

John Emsley

Nature Chemistry 5, 978 (2013); published online 24 October 2013; corrected after print 3 October 2014.

In the version of this In Your Element article previously published, it should have stated that some passages in this essay are based on the manganese chapter in the author's book, Nature's Building Blocks.

\section{ADDENDUM}

\section{In Your Element: The A-Z of zirconium}

John Emsley

Nature Chemistry 6, 254 (2014); published online 20 February 2014; corrected after print 3 October 2014.

In the version of this In Your Element article previously published, it should have stated that some passages in this essay are based on the zirconium chapter in the author's book, Nature's Building Blocks. 